\title{
The System $\mathrm{BaO}-\mathrm{B}_{2} \mathrm{O}_{3}$
}

\section{By Ernest M. Levin and Howard F. McMurdie}

\begin{abstract}
A phase equilibrium diagram of the system $\mathrm{BaO}-\mathrm{B}_{2} \mathrm{O}_{3}$ has been constructed from data obtained essentially by the quenching method. Four congruently melting compounds were identified: $\mathrm{BaO} .4 \mathrm{~B}_{2} \mathrm{O}_{3}$, melting at $879^{\circ} \pm 5^{\circ} \mathrm{C} ; \mathrm{BaO} .2 \mathrm{~B}_{2} \mathrm{O}_{3}$, melting at $900^{\circ} \pm 5^{\circ} \mathrm{C} ; \mathrm{BaO}_{2} \mathrm{~B}_{2} \mathrm{O}_{3}$, melting at $1,095^{\circ} \pm 5^{\circ} \mathrm{C}$; and $3 \mathrm{BaO} . \mathrm{B}_{2} \mathrm{O}_{3}$, melting at $1,383^{\circ} \pm 5^{\circ} \mathrm{C}$. Some optical properties of these compounds were determined with the petrographic microscope, and X-ray diffraction data suitable for their identification were obtained. Barium metaborate, $\mathrm{BaO} \cdot \mathrm{B}_{2} \mathrm{O}_{3}$, showed an inversion occurring between $100^{\circ}$ and $400^{\circ} \mathrm{C}$. Mixtures containing less than 30 percent of $\mathrm{BaO}$ were found to separate on fusion into two liquid layers, one of which contained 30 percent of $\mathrm{BaO}$, whereas the other was nearly pure $\mathrm{B}_{2} \mathrm{O}_{3}$. A curve showing indices of refraction of the quenched glasses is also presented.
\end{abstract}

\section{Introduction}

The study of this system was undertaken as a preliminary to a study of part of the ternary system, $\mathrm{BaO}-\mathrm{B}_{2} \mathrm{O}_{3}-\mathrm{SiO}_{2}$. The latter system is of fundamental importance to the glass industry, as it serves as a starting point for investigations of the barium crown and dense barium crown glasses, which are characterized by high refractive index and low dispersion. The nature of the high silica-boric oxide portion of the ternary system might also have additional application in studies of enamels and ceramic glazes.

R. Benedikt [1] ${ }^{1}$ in 1874 prepared $\mathrm{BaO} \cdot \mathrm{B}_{2} \mathrm{O}_{3}$ by fusion of a sodium borate and barium chloride in molecular proportions and subsequently leaching out the $\mathrm{NaCl}$ from the crystallized melt. H. Ditte [2] in 1873 claimed the preparation of two barium borates: $\mathrm{BaO} .2 \mathrm{~B}_{2} \mathrm{O}_{3}$ and $2 \mathrm{BaO} .3 \mathrm{~B}_{2} \mathrm{O}_{3}$. L. Ouvrard [3] in 1901 obtained $3 \mathrm{BaO} \cdot \mathrm{B}_{2} \mathrm{O}_{3}$.

The first systematic study of the system $\mathrm{BaO}-\mathrm{B}_{2} \mathrm{O}_{3}$ was made by W. Z. Guertler [4] in 1904 . The course of the liquidus curve from about 62 to 84 percent of $\mathrm{BaO}$ was traced by the combined use of cooling curves and of visual observation of the temperatures at which turbidity of the melts occurred. His diagram indicated maxima at

\footnotetext{
1 Figures in brackets indicate the literature references at the end of this paper.
}

$1,060^{\circ} \mathrm{C}, 1,002^{\circ} \mathrm{C}$, and $1,315^{\circ} \mathrm{C}$, corresponding to the compounds $\mathrm{BaO} . \mathrm{B}_{2} \mathrm{O}_{3}, 2 \mathrm{BaO} . \mathrm{B}_{2} \mathrm{O}_{3}$, and $3 \mathrm{BaO}$.$\mathrm{B}_{2} \mathrm{O}_{3}$, respectively. In a study on the limits of miscibility of boric anhydride and borates in the fused state, Guertler [5] found that barium oxide melted together with more than 63.2 percent by weight of $\mathrm{B}_{2} \mathrm{O}_{3}$ separated into two layers. The upper layer was cloudy and soluble in water; the lower one consisted of clear glass that could not be devitrified. Because of the excessive amount of supercooling that occurs in this system, the accuracy of Guertler's results are subject to question.

F. De Carli [6] (1927), using essentially the same method employed by Guertler, extended the liquidus diagram to include the region 33 to 59.5 percent of $\mathrm{BaO}$. He found maxima at $750^{\circ}, 740^{\circ}$, and $810^{\circ} \mathrm{C}$, corresponding to the compounds $\mathrm{BaO} .4 \mathrm{~B}_{2} \mathrm{O}_{3}, \mathrm{BaO} .3 \mathrm{~B}_{2} \mathrm{O}_{3}$, and $\mathrm{BaO} .2 \mathrm{~B}_{2} \mathrm{O}_{3}$, respectively. He also observed that melts containing more than 67 percent by weight of $\mathrm{B}_{2} \mathrm{O}_{3}$ separated into two liquids.

With reference to the "end-members" of the system, the melting point of pure $\mathrm{B}_{2} \mathrm{O}_{3}$ has been reported variously as $294 \pm 1^{\circ} \mathrm{C}$ [7], $460^{\circ}$ to $470^{\circ} \mathrm{C}$ [8], and $450 \pm 2^{\circ} \mathrm{C}$ [9]. Kracek, Morey, and Merwin [9] working with small crystals found them to have a density 2.460 and to be nearly or quite uniaxial negative, with $\omega$ (or $\beta$ and $\gamma$ ) $=$ 
$1.64_{8}$ and $\epsilon($ or $\alpha)=1.61_{5}$. Crushing either induced a minute lamellar twinning or revealed a twinning caused by inversion. Morey [10] reported that colorless $\mathrm{B}_{2} \mathrm{O}_{3}$ glass had a density of 1.812 and a refractive index of 1.458 .

Barium oxide is colorless, cubic, with a density of 5.72 and with $N_{D}=1.980$ [11]. Schumacher [12] has placed its melting point at $1,923^{\circ} \mathrm{C}$.

Because of the almost complete absence of optical and X-ray data on the barium borates, as well as the uncertainty as to the number of compounds and their melting points, it was considered desirable to make a comprehensive study of the system $\mathrm{BaO}-\mathrm{B}_{2} \mathrm{O}_{3}$.

\section{General Procedure}

The general plan followed was to prepare mixtures of $\mathrm{BaO}$ and $\mathrm{B}_{2} \mathrm{O}_{3}$ in varying proportions and to determine their melting points by means of the quenching method. Heating curves obtained by the differential thermocouple method supplemented most of the determinations. The petrographic microscope was used to determine the phases present in the quenched samples. When microscopic identification was uncertain, X-ray diffraction analysis was employed.

\section{Preparation of Mixtures}

Powdered boric acid $\left(\mathrm{H}_{3} \mathrm{BO}_{3}\right)$ was used as a source of $\mathrm{B}_{2} \mathrm{O}_{3}$ for all mixtures. Both crystalline barium nitrate $\left(\mathrm{Ba}\left(\mathrm{NO}_{3}\right)_{2}\right)$ and powdered barium carbonate $\left(\mathrm{BaCO}_{3}\right)$, low in nitrate, were used as a source of $\mathrm{BaO}$. All the chemicals were of reagent quality, meeting ACS specifications. Although barium nitrate was satisfactory for preparing mixtures containing less than 78 percent by weight of $\mathrm{BaO}$, it was found unsuitable for mixtures containing more than 78 percent of $\mathrm{BaO}$. In the latter case, the $\mathrm{Ba}\left(\mathrm{NO}_{3}\right)_{2}$ appeared to melt before combination with $\mathrm{H}_{3} \mathrm{BO}_{3}$, making it difficult to obtain homogeneous mixtures by sintering. For mixtures containing more than 78 percent of $\mathrm{BaO}$, barium carbonate was found to be satisfactory.

For each mixture the calculated amounts of boric acid, and barium nitrate or carbonate were thoroughly mixed and ground together for 2 hours in a mechanical grinder. The mixture was then heated slowly over a period of several hours [13] to a final temperature that was below the solidus, usually about $700^{\circ} \mathrm{C}$. After approximately 2 hours of sintering, the material was ground to pass a No. 200 sieve and was resintered again at a slightly higher temperature, but still below the solidus. The material was subsequently reground to pass a No. 200 sieve. This treatment, in most cases, gave a sufficiently homogeneous product when examined with the polarizing microscope; however, in a few instances it was necessary to sinter the material for a third time. All sintering was done in platinum by using an electrically heated furnace.

For the preparation of mixtures containing more than 87 percent of $\mathrm{BaO}$, the above procedure was found to be inadequate, since the $\mathrm{BaO}$ existed in an uncombined phase and reacted with the platinum crucible. In these instances, it was found expedient to grind together the calculated amount of tribarium borate (containing 86.77 percent of $\mathrm{BaO}$ ) with the required amount of $\mathrm{BaO}$, formed by igniting barium nitrate.

\section{Chemical Analyses}

Because of loss of boric acid by volitilization during preparation of the mixtures, it was necessary to analyze the product in each case. To determine $\mathrm{BaO}$, from 0.5 to $1 \mathrm{~g}$ of the sample was dissolved in an excess of standard $0.3 \mathrm{~N}$ hydrochloric acid, followed by titration (to the $p$-nitrophenol end point) of the excess acid with standard $0.3 \mathrm{~N}$ sodium hydroxide. The $\mathrm{B}_{2} \mathrm{O}_{3}$ was determined on the same sample by adding mannitol and titrating with the standard sodium hydroxide to the phenolphthalein end point.

In general, it was found that mixtures rich either in $\mathrm{BaO}$ or $\mathrm{B}_{2} \mathrm{O}_{3}$ were hygroscopic, whereas the others were only slightly so. This condition was similar to the one observed for the calcium borates [14]. The percentages of $\mathrm{BaO}$ and $\mathrm{B}_{2} \mathrm{O}_{3}$ were adjusted to total 100 percent on a nonvolatile basis, since any moisture present was expelled in the subsequent heating. All mixtures, however, were stored in a desiccator over magnesium perchlorate.

A check chemical analysis of a few selected samples that had been heated to melting during the differential thermal analysis showed no appreciable change in composition and indicated low volatility of combined $\mathrm{B}_{2} \mathrm{O}_{3}$. 


\section{Apparatus and Method}

The thermal studies were made by the well established quenching method [15], supplemented in most cases by the differential thermocouple method [16]. Although the latter method did not produce significant results, it indicated the temperatures of phase changes and thus facilitated the quenching determinations. The furnace was of a vertical tube resistance type [17] wound with 80 -percent-Pt-20-percent-Rh wire. It was operated in connection with a controller that maintained to within 2 degrees the desired temperatures from which the quenches were made. Temperatures were measured with a $\mathrm{Pt}$ vs. $\mathrm{Pt}+10$-percent$\mathrm{Rh}$ thermocouple, which was calibrated periodically against the melting points of gold $\left(1,063^{\circ} \mathrm{C}\right)$, $\mathrm{CaO} . \mathrm{B}_{2} \mathrm{O}_{3}\left(1,154^{\circ} \mathrm{C}\right)[14]$, and $\mathrm{BaO} .2 \mathrm{SiO}_{2}\left(1,418^{\circ}\right.$ C) $[18]$.

Both the quenching and differential thermocouple methods were inadequate for determining the eutectic between $3 \mathrm{BaO} \cdot \mathrm{B}_{2} \mathrm{O}_{3}$ and $\mathrm{BaO}$, because of the rapid rate of devitrification with the former method and the reaction of barium oxide with platinum with the latter. This eutectic was determined, however, by a method of optical pyrometry. The furnace, sample preparation, and procedure are described in Research Papers 1443 and 1703 [19]. The specimen upon which the optical pyrometer was focused was a small four-sided pyramid about $3 / 16$ in. at the base and grooved on each side. It was ground from a compressed cylinder of material, formed by subjecting about half a gram of a mixture of tribarium borate, barium oxide, and one drop of rubber cement to $36,000 \mathrm{lb} / \mathrm{in}^{2}{ }^{2}$, in a $1 / 4$-in.-diameter steel die.

X-ray diffraction powder patterns (with copper $\mathrm{K} \alpha$ radiation) were made of all compounds and certain other samples by using a commercial type Geiger counter X-ray spectrometer equipped with a synchronous-motor-driven scanning unit and attached to an electronic high-speed recorder. A high-temperature X-ray diffraction apparatus [20] was employed for studying inversion forms.

\section{Results}

\section{Binary Compounds}

Four binary compounds were found in the system: $\mathrm{BaO} .4 \mathrm{~B}_{2} \mathrm{O}_{3}, \quad \mathrm{BaO} .2 \mathrm{~B}_{2} \mathrm{O}_{3}, \quad \mathrm{BaO} . \mathrm{B}_{2} \mathrm{O}_{3}$, and $3 \mathrm{BaO} . \mathrm{B}_{2} \mathrm{O}_{3}$. X-ray diffraction data for these compounds are shown in table 1 . In the study of the compounds of the system, no evidence of solid solution was found by optical or X-ray diffraction methods.

TABLE 1. X-ray diffraction data for compounds in the system $\mathrm{BaO}-\mathrm{B}_{2} \mathrm{O}_{3}$, showing the interplanar spacings $(d)$ and their relative intensitities $(R I)$

\begin{tabular}{|c|c|c|c|c|c|c|c|c|c|}
\hline \multirow{2}{*}{\multicolumn{2}{|c|}{$\mathrm{BaO} .4 \mathrm{~B}_{2} \mathrm{O}_{3}$}} & \multirow{2}{*}{\multicolumn{2}{|c|}{$\mathrm{BaO} .2 \mathrm{~B}_{2} \mathrm{O}_{3}{ }^{\mathrm{a}}$}} & \multicolumn{4}{|c|}{$\mathrm{BaO} . \mathrm{B}_{2} \mathrm{O}_{3}$} & \multirow{2}{*}{\multicolumn{2}{|c|}{$\mathrm{BaO} .3 \mathrm{~B}_{2} \mathrm{O}_{3} \mathrm{~d}$}} \\
\hline & & & & \multicolumn{2}{|c|}{$\begin{array}{l}\text { Low tem- } \\
\text { perature } \\
\text { form b }\end{array}$} & \multicolumn{2}{|c|}{$\begin{array}{l}\text { High tem- } \\
\text { perature } \\
\text { form }{ }^{\circ}\end{array}$} & & \\
\hline$d$ & $R I$ & $d$ & $R I$ & $d$ & $R I$ & $d$ & $R I$ & $d$ & $R I$ \\
\hline 1 & 2 & 3 & 4 & 5 & 6 & 7 & 8 & 9 & 10 \\
\hline$A$ & $\begin{array}{l}\text { Per- } \\
\text { cent }\end{array}$ & $A$ & $\begin{array}{l}\text { Per- } \\
\text { cent }\end{array}$ & $A$ & $\begin{array}{l}\text { Per- } \\
\text { cent }\end{array}$ & $A$ & $\begin{array}{l}\text { Per- } \\
\text { cent }\end{array}$ & A & $\begin{array}{l}\text { Per- } \\
\text { cent }\end{array}$ \\
\hline 6.10 & 29 & 6.15 & 70 & 6.25 & 24 & 6.32 & 11 & 4.3 & 14 \\
\hline 5.25 & 49 & 4. 91 & 30 & 3. 91 & 10 & 3.92 & 6 & 3.85 & 31 \\
\hline 4. 11 & 4 & 4. 33 & 30 & 3. 58 & 91 & 3.60 & 100 & 3.70 & 37 \\
\hline 3.90 & 5 & 3.81 & 65 & 3.50 & 100 & -.. & -- & 3. 24 & 87 \\
\hline 3.70 & 5 & 3.55 & 55 & 3. 11 & 25 & 3.13 & 24 & 3.06 & 46 \\
\hline 3.57 & 3 & 3. 39 & 90 & 3.05 & 24 & -- & -- & 3.02 & 64 \\
\hline 3.33 & 100 & 3.25 & 70 & 2. 92 & 12 & 2. 93 & 5 & 2.95 & 39 \\
\hline 3.06 & 17 & 3.13 & 100 & 2. 71 & 6 & -.- & -. & 2.82 & 100 \\
\hline 2. 90 & 52 & 3.06 & 60 & 2.51 & 52 & 2. 54 & 34 & 2. 68 & 29 \\
\hline 2.72 & 11 & 2.81 & 55 & 2.36 & 20 & 2.37 & 12 & 2.52 & 24 \\
\hline 2. 63 & 14 & 2. 50 & 70 & 2.31 & 7 & ... & -- & 2. 36 & 37 \\
\hline 2. 52 & 7 & 2.35 & 35 & 2. 12 & 15 & 2.18 & 6 & 2. 28 & 4 \\
\hline 2.41 & 6 & 2.30 & 45 & 2. 06 & 58 & 2.08 & 42 & 2. 23 & 20 \\
\hline 2. 24 & 39 & 2. 11 & 40 & 2.02 & 23 & 2. 03 & 8 & 1.96 & 39 \\
\hline 2.17 & 3 & 2.04 & 45 & 1. 955 & 10 & -.. & -- & 1. 934 & 27 \\
\hline 2.14 & 18 & 2.00 & 35 & 1. 924 & 7 & ... & - & 1.887 & 20 \\
\hline 2.11 & 11 & ... & -- & 1.829 & 20 & 1.867 & 12 & 1.862 & 44 \\
\hline 2.05 & 3 & ... & -- & 1. 814 & 12 & 1.806 & 6 & 1.790 & 29 \\
\hline 2. 00 & 7 & -.. & -. & 1. 756 & 7 & -.- & -. & 1.734 & 24 \\
\hline 1. 979 & 8 & -- & -- & 1. 639 & 6 & 1. 640 & 3 & 1. 707 & 12 \\
\hline 1. 936 & 6 & ... & -- & 1. 602 & 11 & 1. 612 & 10 & 1.345 & 10 \\
\hline 1. 911 & 6 & -.. & .. & 1. 503 & 7 & 1. 509 & 7 & ... & -- \\
\hline 1. 731 & 3 & -.. & -. & 1. 486 & 7 & -.. & -- & ... & -. \\
\hline 1. 665 & 3 & -.. & -. & 1. 466 & 6 & ... & -. & ... & -- \\
\hline 1. 615 & 6 &.- & - & 1. 382 & 13 & -.. & -- & -.. & -- \\
\hline 1. 547 & 3 & -.. & -- & 1. 363 & 11 & 1. 367 & 4 & ... & -. \\
\hline 1. 516 & 5 & -.. & -- & -.. & -- & -.. & -. & ... & -. \\
\hline 1.410 & 5 & ... & -- & ... & -- & -.. & -. & -.. & -- \\
\hline 1. 354 & 3 & -- & -- & -- & -- & -.. & -- & -.- & -- \\
\hline 1. 253 & 3 & $-\cdot$ & -- & $-\cdot$ & -- & -.. & -- & $-\cdot$ & -- \\
\hline
\end{tabular}

a Weak pattern, poorly crystalline. Only $d$ values with $R I$ greater than 29 recorded.

b Only $d$ values with $R I$ greater than 5 recorded.

- Data obtained with high-temperature X-ray apparatus, at $700^{\circ} \mathrm{C}$. Weak pattern. The $d$ values are not corrected for temperature coefficient.

d Compound hydrates and carbonates rapidly. Pattern determined in sections with fresh samples for each.

$\mathrm{BaO} .4 \mathrm{~B}_{2} \mathrm{O}_{3}$. - This compound occurs as the primary phase in all the mixtures containing up to about 41 percent of $\mathrm{BaO}$. It melts congruently at $879 \pm 5^{\circ} \mathrm{C}$. It appears as irregular grains, many striated as in polysynthetic twinning. It 
is uniaxial negative or biaxial negative with a very small optic axial angle; $\omega$ (or $\beta$ and $\gamma)=$ $1.594,{ }^{2} \epsilon($ or $\alpha)=1.559$. Index of glass $=1.558$.

$\mathrm{BaO} .2 \mathrm{~B}_{2} \mathrm{O}_{3}$. - This compound occurs as the primary phase in mixtures containing approximately 41 to 56 percent of $\mathrm{BaO}$. It melts congruently at $900 \pm 5^{\circ} \mathrm{C}$. It crystallizes in small irregular grains, biaxially positive, moderately birefringent, with medium optic axial angle; $\alpha=1.595, \beta=1.610, \gamma=1.668$. Index of glass $=$ 1.615 .

BaO. $\mathrm{B}_{2} \mathrm{O}_{3}$.- This compound occurs as the primary phase in mixtures containing approximately 56 to 78 percent of $\mathrm{BaO}$. It melts congruently at $1,095 \pm 5^{\circ} \mathrm{C}$. It appears as irregular grains, highly birefringent, uniaxial negative; $\omega=1.667$, $\epsilon=$ about 1.528. Index of glass=1.66. Elongated grains tend to show optic axis figures, with the microscope, which suggests 001 or 0001 cleavage.

Grains of the material examined under the microscope immediately after quenching appear clear and smooth; but after the material has stood for several minutes, the grains have an etch-like appearance over their surface, which interferes with index determinations. At first the change was ascribed to a hydration process, but a sample exposed for 18 hours in the laboratory atmosphere of high relative humidity showed no increase in weight. Studies with the high-temperature X-ray apparatus indicate the existence of two reversible polymorphic forms of the barium metaborate. The temperature of inversion could not be ascertained, as the transition is not sharp, but occurs over a range of $100^{\circ}$ to $400^{\circ} \mathrm{C}$. From table 1 (columns $3,4,5,6)$, it can be seen that the two forms are similar, but that the high temperature form has fewer spacings, the most notable reductions occurring at about 3.5 and $3.05 \mathrm{~A}$. The heat effect of the inversion must be small, as the differential heating curve shows no discontinuity below the melting point.

$3 \mathrm{BaO} . \mathrm{B}_{2} \mathrm{O}_{3}$.-This compound occurs as the primary phase in mixtures containing approximately 78 to 87 percent of $\mathrm{BaO}$. It melts congruently at $1,383 \pm 5^{\circ} \mathrm{C}$. As ordinarily prepared, it crystallizes poorly as "egg-shaped" grains, biaxial negative (?), with low birefringence and undulatory extinction $\alpha=1.756, \gamma=1.768$.

\footnotetext{
${ }^{2}$ Indices, unless stated otherwise, are considered accurate to \pm 0.003 .
}

Tribarium borate hydrates and carbonates rapidly when left in the air. A sample exposed to the air (relative humidity above 90\%) overnight in the X-ray holder gave a sharp pattern of $\mathrm{BaCO}_{3}$. For more carefully controlled conditions, figure 1 shows the gain in weight of a half gram sample

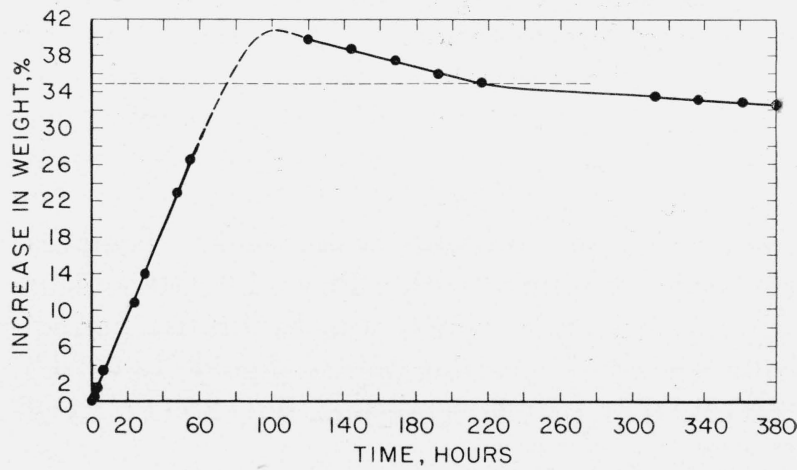

Figure 1. Gain in weight of $3 \mathrm{BaO} \cdot \mathrm{B}_{2} \mathrm{O}_{3}$ when exposed to the atmosphere at $21^{\circ} \mathrm{C}$ and 56 -percent relative humidity.

when exposed to the atmosphere at $21^{\circ} \mathrm{C}$ and 56-percent relative humidity. The maximum gain is approximately 40.8 percent, occurring after about $100 \mathrm{hr}$ of exposure. Assuming that this increase in weight is due almost entirely to hydration and an accompanying decomposition, the condition of the $3 \mathrm{BaO} \cdot \mathrm{B}_{2} \mathrm{O}_{3}$ at the end of $100 \mathrm{hr}$ can be represented as $3 \mathrm{Ba}(\mathrm{OH})_{2}+2 \mathrm{H}_{3} \mathrm{BO}_{3}+6 \mathrm{H}_{2} \mathrm{O}$. Unquestionably, the material is also carbonating during the first $100 \mathrm{hr}$, but the hydration reaction is greater. During this portion of the experiment, the material appears moist and spongy; but later, as the carbonation reaction predominates, it becomes hard and compact. At approximately $215 \mathrm{hr}$ the gain in weight of the sample is about 35 percent and corresponds to complete conversion of the material to $\mathrm{BaCO}_{3}$ and $\mathrm{H}_{3} \mathrm{BO}_{3}$. The presence of these products was verified with the aid of the polarizing microscope.

The experimental results did not confirm the existence of the compounds $\mathrm{BaO} .3 \mathrm{~B}_{2} \mathrm{O}_{3}$ and $2 \mathrm{BaO} \cdot \mathrm{B}_{2} \mathrm{O}_{3}$ reported by De Carli [6] and Guertler [4], respectively.

The composition of $\mathrm{BaO} .3 \mathrm{~B}_{2} \mathrm{O}_{3} \quad(42.33 \%$ of $\mathrm{BaO})$ is close to that of the determined eutectic between $\mathrm{BaO} .4 \mathrm{~B}_{2} \mathrm{O}_{3}$ and $\mathrm{BaO} .2 \mathrm{~B}_{2} \mathrm{O}_{3} \quad(40.6 \%$ of $\mathrm{BaO})$. A sample of sintered material and a sample of glass, both of the composition $\mathrm{BaO} .3 \mathrm{~B}_{2} \mathrm{O}_{3}$ were heated for $66 \mathrm{hr}$ at $853^{\circ} \mathrm{C}$, which temperature was about $6^{\circ}$ below the eutectic. Optical 
and X-ray examination of the products showed them to consist of two conjugate phases. The same two primary phases were present when a mixture of the eutectic composition was heated about 2 deg below the melting temperature for $66 \mathrm{hr}$.

By similar methods, it was concluded that the composition $2 \mathrm{BaO} . \mathrm{B}_{2} \mathrm{O}_{3} \quad(81.50 \%$ of $\mathrm{BaO})$ did not represent a unique compound but a mixture of two conjugate phases, $\mathrm{BaO} \cdot \mathrm{B}_{2} \mathrm{O}_{3}$ and $3 \mathrm{BaO} \cdot \mathrm{B}_{2} \mathrm{O}_{3}$.

\section{Phase Equilibrium Diagram}

The phase equilibrium diagram is shown in figure 2. Mixtures containing less than 30.2 percent of $\mathrm{BaO}$ were found on fusion to separate into two immiscible liquids (for convenience designated as $L_{1}$ and $L_{2}$ in fig. 2.) The heavier glass, which was seen under the microscope to be full of minute spherules of higher index. That the spherules were of approximately the same chemical composition as the heavier glass was indicated by the following experiment: A sample of the glass containing 2.99 percent of $\mathrm{BaO}$ was agitated with water for $10 \mathrm{~min}$; the solution filtered, and the filtrate analyzed volumetrically for $\mathrm{BaO}$ and $\mathrm{B}_{2} \mathrm{O}_{3}$. The filtrate was found to contain 1.98 percent of $\mathrm{BaO}$ and 94.49 percent of $\mathrm{B}_{2} \mathrm{O}_{3}$, based on the original sample weight. The composition of the undissolved glass calculated from these data was 28.6 percent of $\mathrm{BaO}$ and 71.4 percent of $\mathrm{B}_{2} \mathrm{O}_{3}$. A complete separation of the two glasses by differential solubility in water was not possible because of the appreciable solubility of the heavier glass, as noted previously.

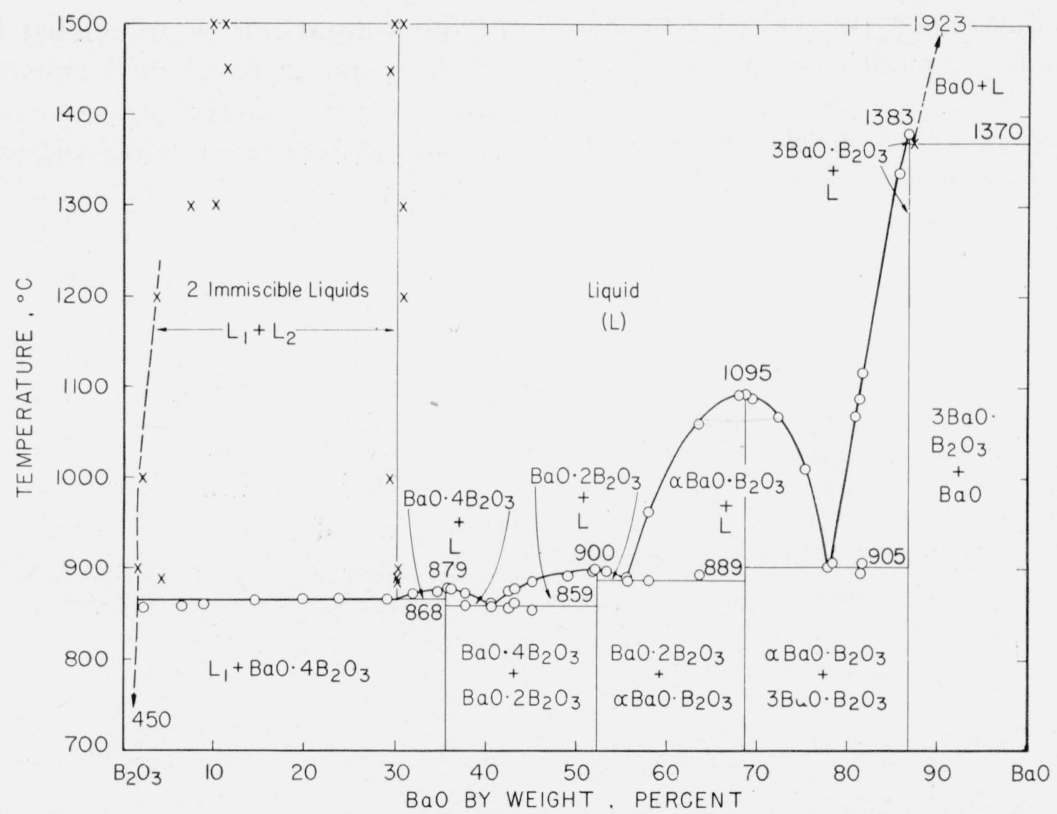

Figure 2. Phase equilibrium diagram for the system $\mathrm{BaO}-\mathrm{B}_{2} \mathrm{O}_{3}$.

of the two liquids $\left(L_{2}\right)$ on cooling formed a clear glass, with a refractive index of 1.536 and a density of about $2.66\left(25^{\circ} \mathrm{C}\right)$. It was soluble in hydrochloric acid and appreciably soluble in water. In one experiment, $0.5 \mathrm{~g}$ of the heavier glass, ground to pass a No. 200 sieve, was agitated for $30 \mathrm{~min}$ in $50 \mathrm{ml}$ of water $\left(27^{\circ} \mathrm{C}\right)$. Under these conditions, about 42 percent of the glass was found to have dissolved. Glass $L_{2}$ contained about 30 percent of $\mathrm{BaO}$, by analysis.

The other liquid $\left(L_{1}\right)$ on cooling formed a cloudy
The index of the lighter glass, quenched from just above the liquidus (about $870^{\circ}$. C), was 1.455 . Within the error of measurement, this value was sufficiently close to that of $\mathrm{B}_{2} \mathrm{O}_{3}$ glass (1.458) to indicate almost pure $\mathrm{B}_{2} \mathrm{O}_{3}$.

An attempt was made to determine the change in composition of the conjugate liquids $L_{1}$ and $L_{2}$ with temperature. Table 2 shows the results of chemical analyses of the mechanically separated layers of charges quenched in air from various temperatures above the liquidus. 
Although the data for the heavier liquid $\left(L_{2}\right)$ show some variation, no significant change in composition occurs up to $1,500^{\circ} \mathrm{C}$. Data for the lighter liquid $\left(L_{1}\right)$ are erratic and more difficult of interpretation. When examined with the microscope, the lighter glass always contained spherules of higher index, indicating that some of liquid $L_{2}$, which had been in solution at higher temperatures, had separated out. Also, as the proportion of occluded material appeared to increase as the temperature from which the quenches were made increased, it seems probable that the solubility of liquid $L_{2}$ in $L_{1}$ had increased with temperature. The results of the chemical analyses, however, are not considered an accurate measure of the extent of solubility of the two liquids at the various temperatures, because of the uncertainty that true and final equilibrium conditions prevailed. This conclusion is indicated by the wide divergence of plotted values from a smooth curve (fig. 2).

TABLE 2. Composition of the immiscible liquids in the system $\mathrm{BaO}-\mathrm{B}_{2} \mathrm{O}_{3}$ at various temperatures

\begin{tabular}{|c|c|c|c|c|}
\hline \multirow{2}{*}{$\begin{array}{c}\text { Tempera- } \\
\text { ture }\end{array}$} & \multicolumn{2}{|c|}{$\begin{array}{c}\text { Composition of } \\
L_{1}\end{array}$} & \multicolumn{2}{|c|}{$\begin{array}{c}\text { Composition of } \\
L_{2}\end{array}$} \\
\hline & $\mathrm{BaO}$ & $\mathrm{B}_{2} \mathrm{O}_{3}$ & $\mathrm{BaO}$ & $\mathrm{B}_{2} \mathrm{O}_{3}$ \\
\hline $\begin{array}{l}{ }^{\circ} \mathrm{C} \\
885\end{array}$ & Percent & Percent & $\begin{array}{c}\text { Percent } \\
30.25\end{array}$ & $\begin{array}{l}\text { Percent } \\
69.75\end{array}$ \\
\hline 890 & 4. 35 & 95.65 & 30.26 & 69.74 \\
\hline 900 & ${ }^{\text {a } 1.58}$ & 98.42 & 30.38 & 69.62 \\
\hline 1,000 & ะ 2.08 & 97.92 & 29.47 & 70. 53 \\
\hline 1,200 & 3. 79 & 96.21 & 30.90 & 69. 10 \\
\hline 1,300 & 10. 23 & 89.77 & 30.78 & 69. 22 \\
\hline 1,300 & a 7.42 & 92.58 & & \\
\hline 1,450 & 11. 52 & 88.48 & 29. 54 & 70.46 \\
\hline 1,500 & 11.25 & 88.75 & 30.69 & 69.31 \\
\hline 1,500 & 10.01 & 89.99 & 29. 95 & 70.05 \\
\hline
\end{tabular}

a Water soluble extract.

To the $\mathrm{BaO}$ side of the immiscibility region, the phase diagram consists of congruently melting compounds and simple eutectics. Table 3 shows the compositions and melting temperatures for the compounds and eutectics in the system. It may be noted that the $\mathrm{BaO} \cdot \mathrm{B}_{2} \mathrm{O}_{3}-3 \mathrm{BaO} \cdot \mathrm{B}_{2} \mathrm{O}_{3}$ eutectic is as low as $905^{\circ} \mathrm{C}$, even with the high $\mathrm{BaO}$ content of about 80 percent. From this point to the melting point of pure $\mathrm{BaO}\left(1,923^{\circ} \mathrm{C}\right)$, the change in temperature is more than $1,000^{\circ} \mathrm{C}$.
TABLE 3. Composition and melting point of compounds ana eutectics in the system $\mathrm{BaO}-\mathrm{B}_{2} \mathrm{O}_{3}$

\begin{tabular}{|c|c|c|c|c|}
\hline \multirow{2}{*}{ Compound } & \multirow{2}{*}{ Eutectic } & \multicolumn{2}{|c|}{ Composition } & \multirow{2}{*}{$\begin{array}{l}\text { Tem- } \\
\text { perature } \\
\left( \pm 5^{\circ} \mathrm{C}\right)\end{array}$} \\
\hline & & $\mathrm{BaO}$ & $\mathrm{B}_{2} \mathrm{O}_{3}$ & \\
\hline \multirow[t]{2}{*}{$\mathrm{BaO} .4 \mathrm{~B}_{2} \mathrm{O}_{3} \ldots$} & $\ldots$ & $\begin{array}{c}\text { Per- } \\
\text { cent } \\
35.51\end{array}$ & $\begin{array}{c}\text { Per- } \\
\text { cent } \\
64.49\end{array}$ & 879 \\
\hline & $\mathrm{BaO} .4 \mathrm{~B}_{2} \mathrm{O}_{3}-\mathrm{BaO} .2 \mathrm{~B}_{2} \mathrm{O}_{3} \ldots$ & 40.6 & 59.4 & 859 \\
\hline \multirow[t]{2}{*}{$\mathrm{BaO} .2 \mathrm{~B}_{2} \mathrm{O}_{3 \ldots}$} & - & 52.41 & 47.59 & 900 \\
\hline & $\mathrm{BaO} .2 \mathrm{~B}_{2} \mathrm{O}_{3}-\mathrm{BaO} . \mathrm{B}_{2} \mathrm{O}_{3} \ldots$ & 55.7 & 44.3 & 889 \\
\hline \multirow[t]{2}{*}{$\mathrm{BaO} . \mathrm{B}_{2} \mathrm{O}_{3}$} & - non & 68.77 & 31.23 & 1,095 \\
\hline & $\mathrm{BaO} \cdot \mathrm{B}_{2} \mathrm{O}_{3}-3 \mathrm{BaO} \cdot \mathrm{B}_{2} \mathrm{O}_{3} \ldots$ & 77.9 & 22.1 & 905 \\
\hline \multirow[t]{2}{*}{$3 \mathrm{BaO} \cdot \mathrm{B}_{2} \mathrm{O}_{3 \ldots}$} & 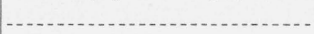 & 86.85 & 13.15 & 1,383 \\
\hline & $3 \mathrm{BaO} \cdot \mathrm{B}_{2} \mathrm{O}_{3}-\mathrm{BaO}$ & 87.3 & 12.7 & 1,370 \\
\hline
\end{tabular}

\section{Index of Refraction of the Quenched Glasses}

Figure 3 shows the index of refraction of quenched glasses and of compounds in the system. Mixtures containing more than about 82 percent of $\mathrm{BaO}$ could not be quenched to glasses because of the rapid rate of devitrification; and, for the same reason, binary glasses containing above 70 percent of $\mathrm{BaO}$ were increasingly difficult to make. Below 30 percent, in the region of liquid immiscibility, two glasses of constant refractive indices always formed, but the amounts of each varied in accordance with the inverse law. The indices are not assumed to represent accurate values for properly annealed glasses, but only an approximation. It is of interest to note that crystalline $\mathrm{BaOB}_{2} \mathrm{O}_{3}$ has a lower average index of refraction than that of glass of identical composition. Such a phenomenon is rather unusual.

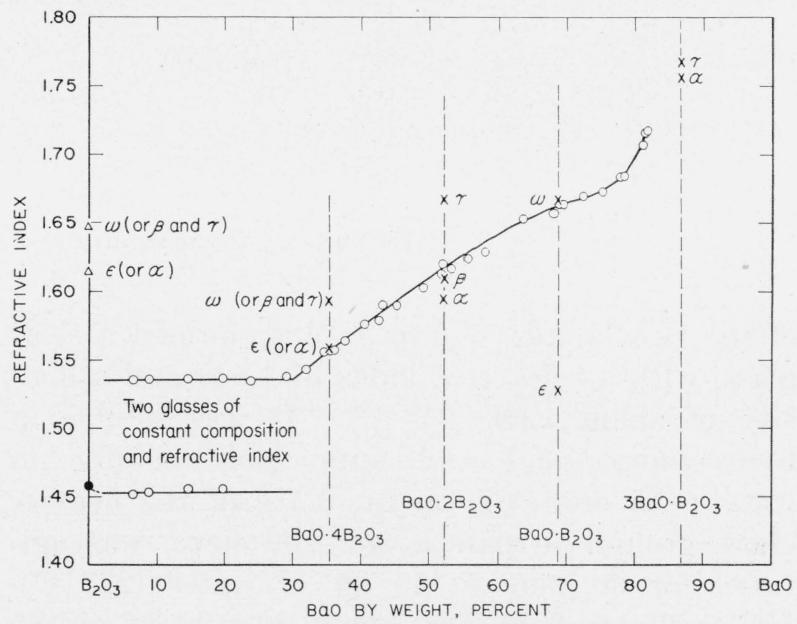

Figure 3. Refractive indices of compounds and of quenched glasses in the system $\mathrm{BaO}-\mathrm{B}_{2} \mathrm{O}_{3}$.

O, Glasses; $-\mathrm{B}_{2} \mathrm{O}_{3}$ glass from Morey [10]; $\times$, compounds; $\triangle, \mathrm{B}_{2} \mathrm{O}_{3}$ crystals from Kracek, Morey, and Merwin [9]. 


\section{Summary}

A phase equilibrium diagram for the system $\mathrm{BaO}-\mathrm{B}_{2} \mathrm{O}_{3}$ has been constructed. A region of liquid immiscibility was found, extending from about 1.6 to 30.2 percent of $\mathrm{BaO}$, and from $868^{\circ}$ to above $1,500^{\circ} \mathrm{C}$. Optical properties, melting points, and X-ray diffraction data were deter- mined for four compounds identified in this system. Some of the data is summarized in table 4, together with the melting points determined by previous investigators. All of the compounds melted congruently, and only one, $\mathrm{BaO} . \mathrm{B}_{2} \mathrm{O}_{3}$ showed an inversion, occurring between $100^{\circ}$ and $400^{\circ} \mathrm{C}$. A curve showing indices of refraction of the quenched glasses is presented.

TABLE 4. Some optical properties of barium borate compounds and ccmpariscn of melting points, as determined by various investigators

\begin{tabular}{|c|c|c|c|c|c|}
\hline \multirow{2}{*}{ Compound } & \multicolumn{2}{|l|}{ Optical properties } & \multicolumn{3}{|c|}{ Melting point determined by - } \\
\hline & Character & Indices of refraction & $\begin{array}{l}\text { Guertler } \\
1904\end{array}$ & $\begin{array}{l}\text { De Carli } \\
1927\end{array}$ & $\begin{array}{l}\text { Levin and } \\
\text { MeMurdie }\end{array}$ \\
\hline - & & & ${ }^{\circ} \mathrm{C}$ & ${ }^{\circ} \mathrm{C}$ & $\pm 5^{\circ} \mathrm{C}$ \\
\hline $\mathrm{BaO} .4 \mathrm{~B}_{2} \mathrm{O}_{3}$ & Uniaxial (-), or biaxial (-) with $2 \mathrm{~V}$ small & $\left\{\begin{aligned} \omega(\text { or } \boldsymbol{\beta} \text { and } \gamma) & 1.594 \\
\epsilon(\text { or } \alpha) & 1.559 \\
\alpha & 1.595\end{aligned}\right.$ & & 753 & 879 \\
\hline $\mathrm{BaO} .2 \mathrm{~B}_{2} \mathrm{O}_{3 \ldots}$ & Biaxial $(+) ; 2 \mathrm{~V}$ medium.. & $\left\{\begin{array}{l}\beta 1.610 \\
\gamma 1.668\end{array}\right.$ & & 810 & 900 \\
\hline $\mathrm{BaO} . \mathrm{B}_{2} \mathrm{O}_{3} \ldots$ & Uniaxial (-) ... & $\begin{array}{r}\omega 1.667 \\
\epsilon \text { about } 1.528\end{array}$ & 1,060 & & 1,095 \\
\hline $3 \mathrm{BaO} . \mathrm{B}_{2} \mathrm{O}_{3-}$ & Biaxial $(-?)$ & 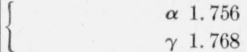 & 1,315 & & 1,383 \\
\hline
\end{tabular}

The authors express their appreciation to E. S. Newman for his aid in obtaining thermal data with an automatically recording unit, and to $\mathrm{S}$. M. Lang, for his help in determining the $3 \mathrm{BaO} . \mathrm{B}_{2} \mathrm{O}_{3}$ $\mathrm{BaO}$ eutectic by an optical pyrometer method.

\section{References}

[1] R. Benedikt, On some salts of boric acid, Ber. deut. chem. ges. $\boldsymbol{7}, 703$ (1874).

[2] H. Ditte, Production by the dry method of several crystalized borates, Compt. rend. 78, 785, 892 (1873).

[3] L. Ouvrard, On the borates of magnesium and the alkaline earth metals, Compt. rend. 132, 257 (1901).

[4] W. Guertler, On the melting points of mixtures of the alkaline earths with boric anhydride, Z. anorg. chem. 40, 337 (1904).

[5] W. Guertler, On the limits of miscibility of boric anhydride and borates in the fused state, Z. anorg. chem. 40, 225 (1904).

[6] F. De Carli, Anhydrous borates of silver, barium, and zinc, Atti Reale acad. Naz. Lincei [6], 5, 41 (1927).

[7] N. W. Taylor and S. S. Cole, Crystalline boric oxide, J. Am. Chem. Soc. 56, 1648 (1934).

[8] L. McCulloch, A crystalline boric oxide, J. Am. Chem. Soc. 59, 2650 (1937).
[9] F. C. Kracek, G. W. Morey, and H. E. Merwin, The system, water-boron oxide, Am. J. Sci. 35A, 143 (1938).

[10] G. W. Morey, Properties of glass, ACS Monograph series No. 77, 227, 370 (Reinhold Pub. Corp., New York, N. Y., 1938).

[11] A. N. Winchell, The microscopic characters of artificial inorganic solid substances or artificial minerals, 2 ed., p. 186 (John Wiley \& Sons, Inc., New York, N. Y. 1931).

[12] E. E. Schumacher, The melting points of barium, strontium, and calcium oxides, J. Am. Chem. Soc. 48, 396 (1926).

[13] M. S. Maksimenko, V. N. Krylov, and M. A. Lipinskii, Dehydration of boric acid to boric anhydride, J. Applied Chem. (USSR) 19, 154 (1946).

[14] E. T. Carlson, The system $\mathrm{CaO}-\mathrm{B}_{2} \mathrm{O}_{3}$, BS J. Research 9, 825 (1932) RP510.

[15] E. S. Shepherd, G. A. Rankin, and F. E. Wright, Binary systems of alumina with silica, lime, and magnesia, Am. J. Sci. [4] 28, 293 (1909).

[16] S. Speil, L. H. Berkelhamer, J. A. Pask, and B. Davies, Differential thermal analysis. Its application to clays and aluminous minerals, U. S. Bur. Mines Tech. Pap. 664, 81 p. (1945).

[17] H. S. Roberts, The Geophysical Laboratory furnace thermostat, J. Opt. Soc. Am. Rev. Sci. Instr. 11, 171 (1925). 
[18] K. T. Greene and W. R. Morgan, The system sodium disilicate-barium disilicate, J. Am. Ceram. Soc. 24, 114 (1941).

[19] R. F. Geller, A resistor furnace with some preliminary results up to $2,000^{\circ}$ C., J. Research NBS 27,555 (1941) RP1443; R. F. Geller, P. J. Yavorsky, B. L. Steierman, and A. S. Creamer, Studies of binary and ternary combinations of magnesia, calcia, baria, beryllia, alumnia, thoria, and zirconia in relation to their use as porcelains, J. Research NBS 36, 277 (1946) RP1703.

[20] A. Van Valkenburg, Jr., and H. F. McMurdie, High-temperature X-ray diffraction apparatus, J. Research NBS 38, 415 (1947) RP1782.

Washington, October 7, 1948. 